\title{
Emergence of New Marketing Distribution Strategies: A Call for A Paradigm Shift
}

\author{
Samuel Affran and Richard Kwabena Asare
}

\begin{abstract}
The purpose of this research is to empirically formulate new distribution strategies that can service the fast moving consumer goods industry and the service industry as a whole. Inspiration was drawn from the orthodox distribution strategies (intensive, selective, and exclusive) currently used in the service industry. To approve its empirical efficacy, the study is set also to determine the impact of these new strategies on sales performance. The study is implemented through a two-stage process of literature review and empirical survey. Evidence was drawn from Ghanaian fast moving consumer goods industry. Structured questionnaire was used to gather data from 415 randomly sampled members in the target population. The data obtained were processed using SPSS version 24. Multiple regression analysis was also used to assess its impact on sales performance. The study revealed that intenelectro aggressive strategy with an average mean of 4.02 is the most adopted strategy by the Fast-Moving Consumer Goods Companies followed by selec-electro aggressive distribution strategy (average mean of 3.81) and exclu-electro aggressive distribution strategy (average mean of 3.74) in that order. The study again revealed that there is a positive significant relationship between inten-electro aggressive strategy and sales performance $\left(R^{2}=.490, \mathrm{p}<0.05\right)$. This newly propounded strategy (inten-electro aggressive strategy) is proven to have a significant impact on sales performance in the fast moving consumer goods industry understudy. Thus, inten-electro aggressive strategy has a moderate positive relationship with sales performance. The statistical implication is that, holding all other variables constant, inten-electro aggressive strategy induces $49.0 \%$ change in sales performance of the fast moving consumer goods firms understudy. Thus, this result proves that a unit change in the effective execution of this strategy will induce $49.1 \%$ change in sales performance. In other words, when inten-electro aggressive strategy is improved by $1 \%$, sales will be improved by 49.0 percentage change. The significance level of this outcome according to the study results was 0.00 which is less than 0.05 indicating that the variance between the two variables in question was significant. The result again proves that exclu -electro aggressive distribution strategy, impact positively on sales performance. It poses as a reasonable positive inclination to sales performance; thus $\left(R^{2}=\right.$ $.595, \mathrm{p}<0.05$ ), Thus, holding all other variables (InEADS \& SeEADS) constant, Exclu -electro aggressive distribution strategy causes $59.5 \%$ change in sales performance. This result proves that a unit change in the efficacy of exclu -electro aggressive distribution strategy in will induce $59.5 \%$ change in the company's sales. The significance level of this outcome in reference to the study results was 0.000 which is less than the standard value of 0.05 indicating that the variance between the two variables in question was significant. Selec-electro aggressive distribution strategy has a positive significant impact on sales performance thus $\left(R^{2}=.532, p<0.01\right)$. It can be
\end{abstract}

Published on December 20, 2019

S. Affran is with the Department of Marketing, Procurement and Supply Chain Management, University of Education Business School, Winneba, Ghana. (e-mail: samuelaffran77@gmail.com).

R. K. Asare is with the Department of Business Studies, College of Distance Education, University of Cape Coast, Ghana. said therefore that any improvement made in selec-electro aggressive distribution strategy, will cause sales performance of FMCG companies to increase by $53.2 \%$.

Index Terms-Affran Marketing Distribution Strategies, Sales Performance, Ghana, Fast-Moving Consumer Goods Industry.

\section{INTRODUCTION}

The marketing function responsible for moving the product to the customer is distribution (Segetlija et al., 2011). In modern business, distribution strategies have a great impact on the success of the business. Hence in order to survive and thrive in highly competitive market, the firm should ensure effective distribution strategies that at any point in time can facilitate distribution of its goods and services. In order to make right decisions regarding all these aspects, the firm requires a complete knowledge of the problems faced in executing its distribution strategies in either urban or rural communities. It is worthy to note that there seems to be a thin line between the needs of urban and rural dwellers, meaning that, it behooves on the channel members not to think that one has a complete upper edge over the other (Grewal \& Dharwadkar, 2012). There is a greater degree of rural base choice that have different consumption pattern of FMCG companies. It is interesting to know that the rural population of this current generation is more oriented towards urban patterns of living and their preferences of FMCG companies are different. The attributes of distribution strategies need to be studied and consequently come out with those appropriate distribution strategies that will serve the firm's target audience better. According to economic distribution channel theory, the "ideal" distribution system or the normative distribution channel can be determined by exploring what the consumers want in terms of service outputs from the distribution channel, how much they are willing to pay for a given quantity of goods, how the product can be offered to them, and what the costs of the alternative distribution channels are (Grewal \& Dharwadkar, 2012). Hence FMCG companies should be able to identify appropriate distribution strategies that will give them competitive advantage. Delivery of the product/service to the final consumer in the right place at the right time, at the right quality and quantity outweigh all other efforts in marketing (Kushwaha, 2012). Unfortunately, many organizations fail to establish or maintain the most effective distribution strategies (Baker \& Hart, 2008; Bikram, 2013). Management decision on how to select the right distribution strategy largely contributes to availability of products to the consumer at the right time and right quantity and quality (Baker \& Hart, 2008). A well 
planned and organized distribution channel is absolutely vital in order to get the firm's product to the final consumer (Aaker, 2009). The reverse is however true with weak distribution strategies adopted by management. Thus, consumers are unable to have finished products from distributors or manufacturers at the right time, and in the right quantity and quality. Thus, the continuous unavailability/shortage of products in some parts of the country could largely be attributed to some of these challenges mentioned above. It is against this backdrop that this study is conducted to empirically ascertain and remodify the marketing distribution strategies existing in the Ghanaian Fast-Moving Consumer Goods industry and also to determine the effect of these new strategies on sales performance.

\section{EMPIRICAL REVIEW OF DISTRIBUTION STRATEGIES}

Distribution strategies play a crucial role in the launch of new products to the market. Distribution is crucial in the eventual acceptance and sales of a new product in the market as it determines the availability of the new product to the customers. Distribution decisions are far reaching because changing them is both resource and time demanding and hence firms have to take great care in designing their distribution systems during the launch of innovations (Rosenbloom, 2007). As distribution strategy plays a role in enabling the availability and application of the product in the marketplace, therefore the distribution strategy employed by the organization would impact the nature of "market support" capability that can be provided to the innovation. The basic distribution intensity strategies that a manufacturer can employ are intensive, selective and exclusive. As stated by Rosenbloom (2007), intensive distribution exists when a manufacturer sells products or services through all or most of the possible channel distributors that provide a particular category of product in a given market. He further clarified that an intensive distribution approach gives manufacturers the highest probability of selling their products or services but only after the required investments in demand generation are made. Kotler (2011) argued that the higher the intensity of brand distribution in a given market, the lower the manufacturer's influence on channel member performance. Moreover, having too many channel partners can harm the brand image and its competitive position. This coverage strategy is more appropriate for manufacturers of brands placed near the low end of the quality continuum to promote convenience and competitive pricing for the customers (Frazier, Maltz, Antia \& Rindfleisch, 2009). Studies have found distribution strategies to include intensive, selective and exclusive distribution strategies (Musso, 2010; Leroy, 2017). These strategies help firms to overcome the challenges associated with distribution. It has been found that, there is no one best strategy to adopt thus each strategy is unique in its own way. This section provides an extensive review of these strategies.

\section{INTENSIVE DistRIBUTION STRATEGY}

Goi (2011) stressed that, intensive distribution strategy ensures that products are convenient, accessible and available to customers at all times. It also ensures that, the firm relies on the market orientation strategy to address customers' demands and also secure several outlets. This therefore prevents external distributors from gaining access to a firm's customer base. Kotler (2011) stressed that, with this strategy, a product is available at maximum number of retail outlets, carried by numerous retailors in a defined area. Products are visible in as many places as possible. It therefore ensures high sales volumes and high product visibility, impulse buying. However, the products are lowpriced and low-margin, thus fast turnover is needed. Due to many retailers, manufacturers give up good control over pricing and product display. According to Slater and Olson (2001) and Kotler (2011), intensive distribution strategy could be measured using indicators such as market orientation, securing many outlets and consumer convenience. It can also be measured using other indicators such as product availability and product accessibility to consumers (Slater \& Olson, 2001; Hult, Ketchen Jr \& Slater, 2005; Hauser \& Shugan, 2008).

\section{Selective Distribution Strategy}

In selective distribution, a manufacturer's product or service is available from more than one channel partner, but the product is not accessible from all businesses that market the category of product (Rosenbloom, 2007). Customers seeking particular brand of product will interact with the businesses in the market that the manufacturers have selected as partners. Selective distribution is a suitable choice when manufacturers would like to design their strategies so that their channel partners have a rather active than passive role (Rosenbloom, 2007). Frazier et al. (2009) argued that manufacturers positioning their brands as high quality have reason to pursue a highly selective distribution policy. Moreover, with this strategy, several retailers have the right to sell the products in specific area. Customers compare these goods on price/quality basis. This strategy has the ability to generate high sales volumes by a relatively small number of retailers. However, the strategy has a risk of inadequate market coverage and choice of retailers and outlets. Retailers can influence producers to reduce the number of retail outlets. According to Nevin (1995) and Frazier et al. (2009), selective distribution strategy could be measured on the basis of customer relationship, focus on outlets, control over outlets or customers and meeting customer's requirements. They were of the view of that, this strategy is centred on selecting customers or outlets in order to fully meet their demands.

\section{EXClusive Distribution StRATEGy}

Exclusive distribution provides high levels of channel partner profitability that allows them to offer functionality consistent with their roles in the 'push' strategy. According to Zhao, NIu and Castillo (2010), exclusive distribution implies that a manufacturer can have strong influence over 
the distributors of the brand. However, manufacturers should be careful because exclusivity may lead to conflict between the manufacturer and the distributors due to the high level of control from the manufacturer's side. Exclusive distribution creates an image of the brand that has superior ability to perform its functions (Zhao et al., 2010). The manufacturers need well-trained sales force to convince the target channel members to carry the brand. The strategy also involves active channel partners and loyal business partnerships between manufacturers, distributors and customers. According to Kotler (2011), a particular retailer sells a product to a specific market segment in a defined geographic area. High price, high margin and lower sales volumes are traits of exclusive distribution. This strategy ensures dealer loyalty, better sales forecasting and inventory control, high level of customer service. However, it could be faced with challenges such as sales volume might be easily lost. When sales are depressed, the retailer can dictate terms to the other channel members. This strategy could be measured in terms of number of retail outlets, control over product image, price dictatorship and mode of involvement (Frazier et al., 2009; Ferrell \& Hartline, 2012).

\section{Distribution Strategies and Sales Performance}

As indicated by Musso (2010), strategic decision on distribution channels is growing in both popularity and significance in the business world. A number of reasons have been assigned for this phenomenon. First, because focus has shifted towards the customer, distribution has moved from being the backwater of strategy to the mainstream, since it is where much of the profit and sales volumes in many industries can be found nowadays (Gebauer, 2009). Put differently, distribution and its systems have become crucial source of increased sales and competitive advantage. This phenomenon has been described quite extensively. Distribution channel strategies affect many other aspects of marketing strategies. According to Kotler (2009), distribution affects sales, since if the product is not available, it cannot be sold. Most customers will not wait until it can be reached. Mouzas and Ford (2009) established that aspects of price that affects effective distribution of the company products includes; high transportation costs, increased inventory management cost, many middle men in the distribution channel and lack of price adjustments. On the other hand, the literature (Neslin \& Shankar, 2009) suggests that the adoption of a new distribution channel may result in channel conflicts. Additionally, multiple-channel structures can be very difficult to manage. According to their arguments, a firm with single-channel strategy would perform better than one with a multiple-channel strategy. Claro and Claro (2010) also argue that the changing business environment has recently challenged many firms to seek out new methods to achieve sustained sales volumes through market orientation and distribution channel collaboration. In the view of expressed by Alrubaiee and Al-Nazer (2010), the prosperity and success of a producer/manufacturer and its distributors hinges on other companies. They further explain that a producer's / manufacturer's success cannot be attained using their own effort; having a good partner in distribution is essentially vital. They also expressed that for businesses to compete effectively in today's competitive environment, there is a need for them to re-evaluate their existing distribution and make adjustments when necessary. Etim, Sunday and Eni (2011) suggest that a multiple-channel strategy may generate more revenue because firms can use different channels to sell different products. When a company starts using a new channel, it can expect higher sales growth through this channel than the channel it has traditionally relied on, because with this new channel a company frequently attempts to tap into a new market segment and therefore enjoys considerable growth opportunities. Moreover, Wright (2012) also posits that a multiple-channel strategy can also reduce costs. Thus, firms with a multiple-channel strategy may perform better than firms with single-channel strategy. A study by Tang, Wang and Wang (2014) noted that supply of china imported goods, existence of many supplier's loss of market share to competitors and quality of competitor products affects distribution of the locally manufactured FMCGs. Gateru, Muturi and Senaji (2015) found out that effectiveness of the company promotion campaigns in creating awareness of the company products influences many customers to FMCG from the competing firms with more effective promotion campaigns. Also, the literature identifies study conducted by Verhoef, Kannan and Inman (2015) which investigates the distribution strategies adopted by various firms in their market and distribution of their products. Particular attention was paid to cosmetic companies. The objective of their study was to find out the various distribution strategies adopted in marketing of wares and the factors influencing adoption of such strategies. The findings of the study revealed that, most of the firms are yet to embrace strategic marketing and distribution ways in order to sell their products and subsequently leap marginal profits. Besides, firms should adopt modern technology in improving their distribution of the products. A study by Lemon and Verhoef (2016) revealed that existence of many firms in the target market leads to increased competition and this makes it difficult for a single company to effectively distribute its product in the competing market and increase its revenue. Ailwadi and Farris (2016) confirmed that lack of distribution of FMCG products in various market segments by many FMCG companies in Kenya can be attributed to an increase in supply of cheap Chinese FMCG products in the market. Nyaga (2016) identified that high level of competition in the market that affects distribution of products is influenced by supply of China imported goods, existence of many suppliers, loss of market shares to competitors and quality of competitor products. It could be deduced that, distribution strategies have been found to influence sales performances of FMCG companies globally (Nyaga, 2016). For instance, current studies by Ailwadi and Farris (2016), Lemon and Verhoef (2016) and Nyaga (2016) confirmed that, distribution strategies help FMCG companies to distribute goods with speed regardless of geographical location. These are clear indications of the contributions of distribution strategies such as intensive, extensive and selective strategies in improving the distribution processes and invariably increasing sales performances. 


\section{RESEARCH FRAMEWORK}

Based on the literature review the research framework is presented in fig. 1. The underlining variables explaining the relationship between the concept ; distribution strategies) on sales performance were carefully selected and remodified to suit the current distribution trends. In a bit to achieve this outcome of the research problem the following hypotheses are developed to guide the study;

H1: If "inten-electro aggressive distribution strategy" is employed, it will have a significant positive influence on sales performance.

H2: If corporate managers, wholesalers and retailers are acquainted with "exclu-electro aggressive distribution strategy," then there will be a positive inclination towards sales performance.

H3: "Selec-electro aggressive distribution strategy" will have a significant positive influence on the company's sales performance.

I therefore propose this conceptual framework to guide this study.Fig. 1

\section{PROPOSED CONCEPTUAL FrAMEWORK}

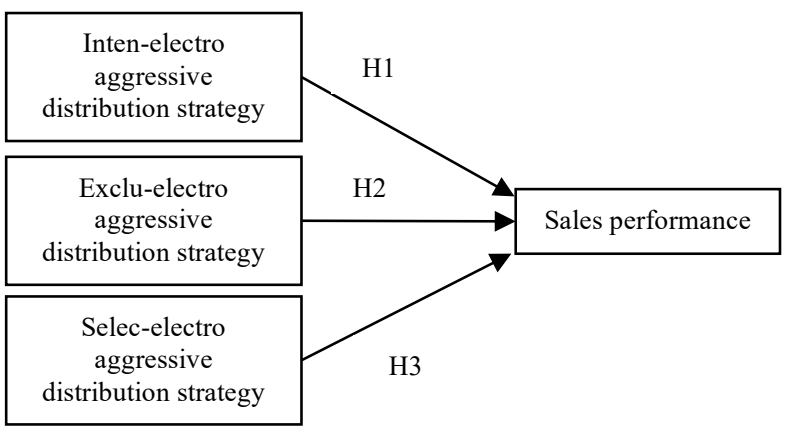

Fig. 1. Affran marketing distribution strategies Source: Developed for the study

The conceptual framework seeks to prove that these newly propounded distribution strategies (Affran marketing distribution strategies) have a very sound relationship with company's sales performance. Empirically the Affran marketing distribution strategy(ies) is defined as the synergistic blending of the physical and electronic modes of transporting goods and services coupled with a well formulated integrated marketing communication programme to achieve the specific distribution objectives. From Figure 1 , the independent variable was represented by distribution strategies such as inten-electro aggressive, selec-electro aggressive and exclu-electro aggressive distribution strategies whereas the dependent variable was represented by sales performance. A quick explanation to some key variables in the model; Inten: (intensive) - Maximum intensity of the physical distribution of goods and service to the target audience. Exclu: (exclusive) - exclusive intensity of the physical distribution of goods and service to the target audience. Selec: (selective) - marginal intensity of the physical distribution of goods and service to the target audience. Electro: (electronic) -electronic distribution of goods and services powered with integrated marketing communication stimuli. Aggressive: The simultaneous application of IMC tools to buttress the physical and electronic distribution of goods and service to the respective target audience. Thus, “inten-electro aggressive distribution strategy" is defined as the maximum intensity of the physical and electronic distribution of goods and services powered with integrated marketing communication stimuli. While "Exclu-electro aggressive distribution strategy" is the exclusive intensity of the physical and electronic distribution of goods and services powered with integrated marketing communication stimuli. Lastly, "selec-electro aggressive distribution strategy" is the marginal intensity of the physical and electronic distribution of goods and services powered with integrated marketing communication stimuli. Thus for an effective, speed and accurate distribution there is the need for multiple combination of these strategies propounded. Distribution in this era is never complete until it is totally linked integratively with the marketing communication elements.

\section{Methodology}

The study employed the Krejcie and Morgan (1970) sampling size determination table to obtain the minimum sample of 415 from the total population (retailers: 311 , wholesalers: 70, distributors: 34). A structured questionnaire, primary data collection instrument, was used for the data collection. The questionnaire was appropriate and as such, designed to meet the stated objectives of the study. The questionnaire was made up of close - ended questions which gave respondents the opportunity to respond to specific issues of the study. The data was then processed using SPSS version 24. Descriptive and inferential statistical tools such as Pearson Product Moment correlation and multiple regression were employed to analysis the study's data. The correlation analysis was first carried out to examine the relationship among the variables. Each variable was run against sales performance to assess the relationship. The relationships were tested at .01 significant level with (99\%) confidence level. The strength of the relationship between the independent and the dependent variables were interpreted using Cohen's (1988) guideline. The guideline showed that, $\mathrm{r}=.10$ to .29 represented a very weak relationship, $r=.30$ to .49 represented a weak relationship, $r=.50$ to .69 represented a moderate relationship and finally, $r=.70$ to .99 represented a strong relationship between the variables.

\section{Results AND Discussion}

TABLE I: INTEN-ELECTRO AGGRESSIVE DISTRIBUTION STRATEGIES OF FASTMOVING CONSUMER GOODS COMPANIES

\begin{tabular}{lll}
\hline \hline $\begin{array}{l}\text { Inten-electro aggressive distribution } \\
\text { strategies }\end{array}$ & Mean & Std. Deviation \\
\hline Market orientation strategy & 3.86 & 1.026 \\
\hline $\begin{array}{l}\text { Secure many outlets (both physical \& } \\
\text { electronically) }\end{array}$ & 3.48 & 1.090 \\
$\begin{array}{l}\text { Product availability to customers ( both } \\
\text { physical \& electronically) }\end{array}$ & 4.07 & .884 \\
\hline Product accessibility to customers & 4.14 & .789 \\
\hline Consumer convenience & 4.38 & .728 \\
\hline Aggressive IMC programme & 4.17 & .624 \\
\hline Average mean & 4.02 & \\
\hline \hline
\end{tabular}

Source: Field survey, Affran et al (2019) 
Table I revealed that, for fast moving consumer goods companies to fully execute this strategy they have to adopt the following tactical operations the first is to ensure that their products are accessible to customers. The degree of accessibility depends on the distribution vehicles they employ. This result reported a higher mean with standard deviation ( $\mathrm{M}=4.14 ; \mathrm{SD}=.789)$. This means that, fast moving consumer goods firms should ensure that customers can easily obtain and understand their products. Due to fierce competitions in the distribution businesses, in recent times, fast moving consumer goods firms have been induced to get their products closer to customers while ensuring that their product specifications are clearly understood using other electronic distribution platforms in addition to the orthodox ones. This finding was in line with a study by Zikmund and d'Amico (2011) who stressed that, product accessibility is an important aspect of Intensive distribution strategy. Also, Kotler et al. (2009) revealed that, intensive distribution strategy focuses on making products accessible to customers. The second tactical operation as an aspect of the inten-electro aggressive strategy is to ensure the availability of products to customers (both physical and electronically) obtaining a mean and standard deviation $(\mathrm{M}=4.07$; $\mathrm{SD}=.884$ ). This means that, firms that adopt this strategy should ensure that they make their products available to customers as and when needed. This implies that, failing to make products available to customers as and when needed could affect the effectiveness of inten-electro aggressive strategy. This can be achieved by aggressively supporting with a comprehensive integrated communication programme $(\mathrm{M}=4.17 ; \mathrm{SD}=.624)$ intended to inform prospective customers about the existence of the goods or service at that particular outlet. According to Kotler et al. (2009), firms make products available to customers by setting up several distribution centres at vantage points and ensure optimum levels at all times. As firms establish several outlets, it prevents external distributors from gaining access to a firm's customer base. Also, the table revealed that, firms moderately rely on the market orientation strategy as an aspect of inten-electro aggressive strategy. The result had a moderate mean with standard deviation $(\mathrm{M}=3.86$; $\mathrm{SD}=1.026$ ). This means that, fast moving consumer goods firms adopt this operational tactic to ensure that customers' needs are identified and that provide products that satisfy them. This result implies that, in adopting Inten-electro aggressive strategy, firms pay minimal attention to identifying customers' needs and this could be because, they act as intermediaries and an as such expect the manufacturers to carry out extensive market research to ensure that they are producing to directly satisfy their customers. This finding was supported by Vibhash and Lakshmi (2008) who revealed that, fast moving consumer goods firms struggle to ensure market orientation due to the presence of economic issues such as costs which could increase overall distribution costs. Market orientation focuses on discovering and meeting the needs and/or requirements of customers through its product mix. It is, therefore, a coordinated marketing campaign between a supplier and its buyers with the view of meeting customer demands. Finally, the aspect of inten-electro aggressive strategy that fast moving consumer goods firms least focused on was their ability to secure several outlets. This result produced the lowest mean with standard deviation $(\mathrm{M}=3.48 ; \mathrm{SD}=1.090)$. This means that, in as much as firm intend to make their products accessible and availability to customers at all times, they struggle to open several outlets. This could be due to lack of funds to secure and manage several outlets. Studies have revealed that, intermediaries of fast moving consumer goods firms are dominated by small businesses with limited capital thus they struggle to expand their operations. This finding was in line with a study by Kotler et al. (2009) and Rosenbloom (2007). Rosenbloom (2007), for instance, revealed that, having too many channel partners/outlets can harm the brand image and the competitive positions of intermediaries. In conclusion an average mean of 4.02 depicts those firms in the fast moving consumer goods industry view inten-electro aggressive strategy as a determinant of market distribution strategy in this current dispensation.

TABLE II: SELEC-ELECTRO AGGRESSIVE DISTRIBUTION STRATEGIES OF FASTMOVING CONSUMER GOODS COMPANIES

\begin{tabular}{lcl}
\hline \hline \multicolumn{2}{l}{ Selec-electro aggressive distribution strategies Mean } & Std. Deviation \\
\hline Good customer relationships & 4.28 & .797 \\
\hline $\begin{array}{l}\text { Focus on several outlets (both physical } \\
\text { electronic) }\end{array}$ & $\&_{3.14}$ & 1.093 \\
\hline Control over outlets or customers & 3.72 & .996 \\
\hline Customers' requirements on time & 3.83 & 1.002 \\
\hline Aggressive IMC programme & 4.08 & .702 \\
\hline Average mean & 3.81 & \\
\hline \hline
\end{tabular}

Source: Field survey, Affran et al (2019)

The results in Table II show that fast moving consumer goods firms adopt selec-electro aggressive strategy in order to establish a good relationship with its customers. This operational strategy had the highest mean with standard deviation $(\mathrm{M}=4.28 ; \mathrm{SD}=.797)$. Firms in this industry chose few outlets both physical and electronically to showcase their products. Thus the distribution intensity is quite marginal but aggressively should be supported with an integrated marketing communication programme to achieve its distribution objective ( $\mathrm{M}=4.08 ; \mathrm{SD}=.702)$. Meeting customer requirements on time is the second underlying reason why fast moving consumer goods firms might resort to selec-electro aggressive strategy (3.83; $\mathrm{SD}=1.002)$. This implies that, meeting customer requirement is a key objective of firms that adopt selec-electro aggressive strategy. Kotler et al. (2009) revealed that, it is appropriate companies to meet customers' requirements by allowing them to compare designs, prices, styles and other features of their products. Moreover, fast moving consumer goods companies adopt this strategy in order to have moderate control over their outlets or customers. This is because, the result had a moderate mean with standard deviation $(\mathrm{M}=3.72 ; \mathrm{SD}=.996)$. This means that, the presence of other intermediary firms and actors induce some wholesalers and retailers to have some level of control over their customers. This would ensure that, intermediaries develop strategic relationships with customers and in turn deliver products that meet their requirements. This finding was in line with a study by Kotler et al. (2009) who found that, intermediaries have adequate market coverage with more control over their outlets and customers. Finally, the table revealed that, although fast moving consumer goods firms adopt selec- 
electro aggressive strategy, they pay minimal attention on opening several outlets. This result had the lowest mean with standard deviation $(\mathrm{M}=3.14 ; \mathrm{SD}=1.093)$. This means that, fast moving consumer goods firms pay more attention to establishing few outlets other than several outlets. This could be because, establishing few outlets would ensure that firms have adequate control over their activities and thus are easily able to exert maximum control over them. This finding was in line with a study by Yeboah et al. (2013) who found that, having less intensive distribution outlets is a major focus of select distribution strategy. This would ensure that FMCG companies have medium level of control over their customers. An average mean of 3.81 proves empirically that fast moving consumer goods firms have adopted selec-electro aggressive strategy as a marketing distribution strategy.

TABLE III: EXCLU-ELECTRO AGGRESSIVE DISTRIBUTION STRATEGIES OF FAST-MOVING CONSUMER GOODS COMPANIES

\begin{tabular}{lll}
\hline \hline & Mean & Std. Deviation \\
\hline Limited retail outlets & 3.24 & 1.123 \\
\hline Control over product image & 3.79 & .940 \\
\hline Firm dictates prices & 3.83 & 1.037 \\
\hline High involvement & 3.62 & 1.083 \\
\hline Aggressive IMC programme & 4.20 & .845 \\
\hline Average mean score & 3.74 & \\
\hline \hline
\end{tabular}

Source: Field survey, Affran et al (2019)

The table revealed that fast moving consumer goods companies adopted the exclu-electro aggressive strategy in order to dictate prices. This result had the highest mean with standard deviation $(\mathrm{M}=3.83 ; \mathrm{SD}=1.037)$. This implies that, prices of products can be dictated by the companies in order to have strong influence over their consumers. This strategy could be employed when the firm have strong brand images in the market. This finding was in line with a study by Zhao et al. (2010) who found that, fast moving consumer goods companies could adopt exclusive distribution strategy in order to dictate prices of their products for control purposes. Also, the table revealed that, fast moving consumer goods companies adopt this strategy in order to have control over their corporate images. This result had a mean with standard deviation $(\mathrm{M}=.790 ; \mathrm{SD}=.940)$. This means that, firms that adopt this strategy are able to control their brand or corporate images over others. This implies that, having control over one's brand image is key to its growth and competitiveness. This finding was in line with a study by Ferrell and Hartline (2011) and Kotler et al. (2009). They found that, exclusive distribution strategy has the traits of focusing on a specific market and also selling at high prices in bid to ensure that firms have adequate control over their corporate or brand images. Moreover, Table III revealed that, fast moving consumer goods companies adopt excluelectro aggressive strategy in bid to have high involvement in their distribution activities. This result had a high mean with standard deviation $(\mathrm{M}=3.62 ; \mathrm{SD}=1.083)$. This implies that, firms that adopt the do not want to encourage subcontracting their core activities (distribution or retailing) to other firms. This could be because, they intend to have control over their consumers in bid to dictate prices and also control their brand images. This finding was in line with a study by Ferrell and Hartline (2011) who revealed that, high involvement is a key aspect of exclusive distribution strategy. They added that, firms are able to control their inventories and ensure high level of customer service whenever they adopt this strategy. Finally, the table revealed that this strategy is appropriate not necessarily because they intend to have limited retail outlets. This is because, the result had the lowest mean with standard deviation $(\mathrm{M}=3.24$; $\mathrm{SD}=1.123$ ). This means that, companies adopt the strategy due to other factors such as control brand image, control customers and ensure high level of involvement other than establish limited retail outlets. This implies that, companies could adopt this strategy and still have the ability to control several retail outlets. Also, although companies adopt this strategy to sell to a specific market, they could require several outlets in bid to achieve their objectives. This finding was in line with studies by Ferrell and Hartline (2011) and Kotler et al. (2012) who found that, firms adopt exclusive distribution strategy in order to sell products to specific market segments in a defined geographic area. Thus, companies could have several retail outlets within a defined geographic area. Finally, the study's result revealed that, the intensive distribution strategy (IDS) was the most adopted strategy by the FMCG companies within the Central Region of Ghana. This result had the highest overall average score $(M=3.99)$. This result was followed by the selective distribution strategy (SDS) with an overall average score of 3.74. Finally, exclusive distribution strategy was identified as the strategy which was least adopted by the FMCG companies $(M=3.62)$. This implies that, FMCG companies are customer-centric thus rely on IDS in bid to make products accessible, available and convenient to customers. They also secure several outlets in order to make their products available to their customers.

\section{Reliability}

TABLE IV: RELIABILITY STATISTICS

\begin{tabular}{cccc}
\hline Variables & $\begin{array}{c}\text { Cronbach's } \\
\text { Alpha }\end{array}$ & $\begin{array}{c}\text { Cronbach's Alpha } \\
\text { Based on } \\
\text { Standardized Items }\end{array}$ & $\begin{array}{c}\text { Number } \\
\text { of Items }\end{array}$ \\
\hline $\begin{array}{c}\text { Inten-electro } \\
\text { aggressive distribution strategy }\end{array}$ & .707 & .708 & 6 \\
$\begin{array}{c}\text { Selec-electroaggressive } \\
\text { distribution } \\
\begin{array}{c}\text { Exclu-electro- } \\
\text { aggressive distribution } \\
\text { strategy }\end{array}\end{array}$ & .745 & .704 & 5 \\
$\begin{array}{c}\text { Sales performance } \\
\text { Strategy }\end{array}$ & .823 & .789 & 5 \\
\hline
\end{tabular}

The Cronbach's alpha coefficient results, as presented in Table IV shows that all the scales for measuring the variables in the study exceed the universally accepted value of 0.7 , inten-electro aggressive distribution strategy recorded a Cronbach's Alpha of 0.707 which demonstrates that, the items used in measuring the variable in question were reliable. Likewise, the Cronbach's Alpha result for measuring the selec-electro aggressive distribution strategy was 0.795 which depicts that the objects used in measuring the variable was highly reliable in terms of analysis making. Similarly, the Cronbach's Alpha coefficient for excluelectro aggressive distribution strategy was .823 which in essence stipulates that the items and scale in measuring the variable was highly accurate and reliable. Again, the Cronbach's Alpha coefficient for sales performance was 
.878 which in turn asserts that the items and scale in measuring sales performance was highly accurate and reliable.

\section{CORRElational Analysis AmONG StUdy VARIABLES}

In establishing the relationships among the variables understudy, the Pearson's product moment correlation analysis was used. The results revealed positive relationships among the variables as shown in the Pearson's product moment correlation matrix in Table V.

TABLE V: CORRELATION RESULTS

\begin{tabular}{|c|c|c|c|c|}
\hline & & InEAS SeEAS & ExEAS & $\overline{\mathrm{SSP}}$ \\
\hline & Pearson Corr. & 1 & & \\
\hline \multirow[t]{2}{*}{ InEAS } & Sig. (2-tailed) & & & \\
\hline & $\mathrm{N}$ & 414 & & \\
\hline \multirow{3}{*}{ SeEAS } & Pearson Corr. & $.574^{* *} 1$ & & \\
\hline & Sig. (2-tailed) & .000 & & \\
\hline & $\mathrm{N}$ & 414 & & \\
\hline \multirow{3}{*}{ ExEAS } & Pearson Corr. & $.582^{* *} .421^{* *}$ & 1 & \\
\hline & Sig. (2-tailed) & $\begin{array}{ll}.000 & .000 \\
\end{array}$ & & \\
\hline & $\mathrm{N}$ & $414 \quad 414$ & 414 & \\
\hline \multirow{3}{*}{ SP } & Pearson Corr. & $.596^{* *} .424^{* *}$ & $.565^{* *}$ & 1 \\
\hline & Sig. (2-tailed) & $\begin{array}{ll}.000 & .000 \\
\end{array}$ & .000 & \\
\hline & $\overrightarrow{\mathrm{N}}$ & 414 & 414 & 414 \\
\hline
\end{tabular}

Correlation significant at the 0.01 level (2-tailed).

Source: Field survey, Affran et al (2019)

The table showed the strength and magnitude of the relationships between the independent and dependent variables. In terms of the relationship between inten-electro aggressive distribution strategy and sales performance, the correlation coefficient (r) using Pearson product moment correlation was $.596^{* *}$ which was significant at $\rho=$ $0.00<0.01$. This means that, there was a significantly positive and moderate relationship between the variables. This implies that, an increase in inten-electro aggressive distribution strategy will lead to a significant but moderate increase in sales performance and vice versa. Also, the table showed the strength and magnitude of the relationship between selec-electro aggressive distribution strategy and sales performance. In terms of the relationship, the correlation coefficient ( $\mathrm{r}$ ) using Pearson product moment correlation was $.424^{* *}$ which was significant at $\rho=$ $0.00<0.01$. This means that, there was a significantly positive but weak relationship. This implies that, an increase in selective distribution strategy will lead to a significant but weak increase in sales performance and vice versa. This could explain why most FMCG companies prefer InEADS to SeEADS. Finally, Table V showed the strength and magnitude of the relationship between exclu-electro aggressive distribution strategy and sales performance. In terms of the relationship, the correlation coefficient (r) using Pearson product moment correlation was $.565^{* *}$ which was significant at $\rho=0.00<0.01$. This means that, there was a significantly positive and moderate relationship ExEADS and SP. This implies that, an increase in exclu-electro aggressive distribution strategy will lead to a significant but moderate increase in sales performance and vice versa.

\begin{tabular}{lllll}
\hline \hline Model & $\mathrm{R}$ & $\mathrm{R}$ Square & $\begin{array}{l}\text { Adjusted } \\
\text { Square }\end{array}$ & $\begin{array}{l}\mathrm{R} \\
\begin{array}{l}\text { Std. Error of } \\
\text { the Estimate }\end{array}\end{array}$ \\
\hline 1 & $.657^{\mathrm{a}}$ & .432 & .428 & 5.45475 \\
\hline \hline
\end{tabular}

Hence from Table VI, the 'Affran marketing distribution strategies' and sales performance were positively correlated, and the strength of the relationship was moderate at $0.657^{\mathrm{a}}$. The R squared which is the coefficient of determination is the proportion of variation in the dependent variable explained by the regression model. Thus, about $(43.2 \%)$ of the variation that existed in sales performance was caused by the distribution strategies. Also, the Adjusted $\mathrm{R}^{2}$ of (42.8\%) explained the variation in sales performance that was being explained by adjustments in the distribution strategies in the regression model. It implies that, the Affran marketing distribution strategies could positively cause a change in sales performance thus they should be continuously improved. Table VII also presented the ANOVA result which provided the test significance for $\mathrm{R}$ and $\mathrm{R}^{2}$ using the F-statistic. The $\mathrm{F}$ statistic was the regression mean square (MSR) divided by the residual mean square (MSE). If the significance value of the F statistic is small (smaller than say 0.05) then the independent variables do a good job in explaining the variation in the dependent variable.

TABLE VII: ANOVA

\begin{tabular}{lllllll}
\hline \hline \multirow{2}{*}{ Model } & $\begin{array}{l}\text { Sum } \\
\text { Squares }\end{array}$ & of & df & $\begin{array}{l}\text { Mean } \\
\text { Square }\end{array}$ & F & Sig. \\
\hline \multirow{3}{*}{1} & Regression & 9267.762 & 3 & 3089.254 & 103.825 & $.000^{\mathrm{b}}$ \\
\cline { 2 - 7 } & Residual & 12199.265 & 410 & 29.754 & & \\
\cline { 2 - 7 } & Total & 21467.027 & 413 & & & \\
\hline
\end{tabular}

From Table VII, the analysis showed the $\rho$-value was well below $.01(\rho=0.00)$. This means that, $R$ and $R^{2}$ between the distribution strategies and sales performance was statistically significant, and therefore they significantly influence sales performance. Thus, any increase in these distribution strategies could invariably increase sales performance of FMCG companies. This implies that, adopting these distribution strategies could have immense influence on their sales performance.

\section{Multiple Regression AnAlysis}

From previous discussions of the findings of this study, the relationship between the variables under study has been established and there is the need to know their impact on sales performance. 
XIV. Multiple Regression Analysis of "AfFran MARKETING DISTRIBUTION STRATEGIES “ON SALES PERFORMANCE

TABLE VIII: COEFFICIENTS

\begin{tabular}{|c|c|c|c|c|c|c|}
\hline \multirow{2}{*}{\multicolumn{2}{|c|}{ Model }} & \multicolumn{2}{|c|}{$\begin{array}{l}\text { Unstandardized } \\
\text { Coefficients }\end{array}$} & \multirow{2}{*}{$\begin{array}{l}\text { Standardized } \\
\text { Coefficients } \\
\text { Beta } \\
\end{array}$} & \multirow[t]{2}{*}{$\mathrm{t}$} & \multirow[t]{2}{*}{ Sig. } \\
\hline & & B & Std. Error & & & \\
\hline \multirow{4}{*}{1} & (Constant) & 2.873 & .995 & & 2.889 & .004 \\
\hline & InEADS & .490 & .069 & .363 & 7.093 & .000 \\
\hline & SeEADS & .532 & .065 & .082 & 1.783 & .000 \\
\hline & ExEADS & .595 & .086 & .320 & 6.939 & .000 \\
\hline
\end{tabular}

a. Dependent Variable: SP

Source: Field survey, Affran et al (2019)

\section{REVISITING THE CONCEPTUAL FRAMEWORK}

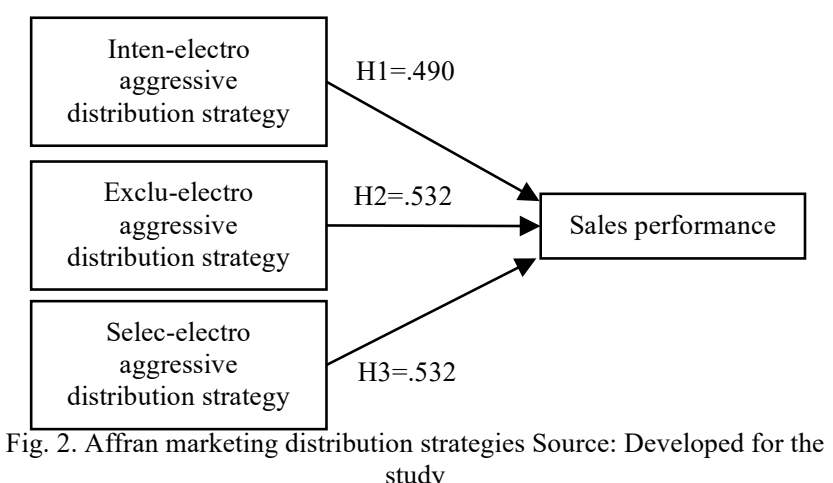

Fig. 2. Affran marketing distribution st
study

\section{THE IMPACT OF “AFFRAN MARKETING DISTRIBUTION STRATEGY” ON SALES PERFORMANCE}

\section{A. Inten-electro aggressive distribution strategy impacts positively on sales performance}

$\mathrm{H} 1$ :(If "inten-electro aggressive distribution strategy" is executed effectively it will have a significant positive influence on sales performance.)

Table. VIII exhibits positive significant relationship between inten-electro aggressive strategy and sales performance $\left(R^{2}=.490, \mathrm{p}<0.05\right)$. This newly propounded strategy (inten-electro aggressive strategy) is proven to have a significant impact on sales performance in the fast moving consumer goods industry understudy. Thus, inten-electro aggressive strategy has a moderate positive relationship with sales performance. The statistical implication is that, holding all other variables constant, inten-electro aggressive strategy induces $49.0 \%$ change in sales performance of the fast moving consumer goods firms understudy. Thus, this results proves that a unit change in the effective execution of this strategy will induce $49.1 \%$ change in sales performance. In other words when inten-electro aggressive strategy is improved by $1 \%$, sales will be improved by 49.0 percentage change. The significance level of this outcome according to the study results was 0.00 which is less than 0.05 indicating that the variance between the two variables in question was significant.

\section{B. Exclu -electro aggressive distribution strategy, impact positively on sales performance}

H2: (If corporate managers, wholesalers and retailers execute "exclu-electro aggressive distribution strategy," then there will be a positive inclination towards sales performance.)

The study has proven that exclu -electro aggressive distribution strategy, impact positively on sales performance. It poses as a reasonable positive inclination to sales performance; thus $\left(R^{2}=.595, \mathrm{p}<0.05\right)$, and hence hypothesis two of the study was accepted. Thus, holding all other variables (InEADS \& SeEADS) constant, Exclu electro aggressive distribution strategy causes $59.5 \%$ change in sales performance. This result proves that a unit change in the efficacy of exclu -electro aggressive distribution strategy in will induce $59.5 \%$ change in the company's sales. The significance level of this outcome in reference to the study results was 0.000 which is less than the standard value of 0.05 indicating that the variance between the two variables in question was significant.

\section{Selec-electro aggressive distribution strategy has a positive impact on sales performance}

(H3: "Selec-electro aggressive distribution strategy" will have a significant positive influence on the company's sales performance.)

The results in Table VIII indicates that selec-electro aggressive distribution strategy has a positive significant impact on sales performance thus $\left(R^{2}=.532, \mathrm{p}<0.01\right)$. It can be said therefore that any improvement made in selecelectro aggressive distribution strategy, will cause sales performance of FMCG companies to increase by $53.2 \%$. In other words, when managers of fast moving consumer goods firms improve or enhance this strategy by $1 \%$, it will originate an increase of $53.2 \%$ sales performance. The significance level (p) of this result in reference to the study was 0.00 which is less than the unified value of significance 0.01 indicating that the variance between the two variables in question was significant. Hence the hypothesis three of the study was accepted.

\section{IMPLICATIONS}

This study has established an emphatic evidence proven with a data that businesses within the fast moving consumer goods industry needs to take a complete turnaround from the orthodox distribution strategy when it comes to delivering their goods and service to their target audience. It's call for a paradigm shift from the just intensive distribution strategy to inten-electro aggressive distribution strategy. This implies that distribution is not just transporting the goods physically from the point of production to the final consumer. Instead it involves applying both physical and electronic conduits powered with well-rehearsed integrated marketing communication stimuli. This strategic intent is to push the goods or service to the final consumer more speedily, accurately and promptly as well. It leaves no stone unturned because it progressively informs the consumer of the physical or electronic position of the goods during the distribution process. Thus, businesses desiring to adopt this new strategy are expected to secure more outlets physically and electronically with a strong market orientation policy. Products are to be made available, accessible to the customers' convenience. The entire process needs to be intertwine with an aggressive marketing communication programme. Again this study has proven that managers in 
this industry have unanimously agreed to adopt selec-electro aggressive strategy instead. This strategy calls for the following: strategically focusing on some selected outlets on the ground alongside the electronic platform. Develop a tactical strategy of delivering customers' requirements on times. Formulate good customer relationships management to beef up the existing relationship with customers. Excluelectro aggressive distribution strategy conveniently replaces extensive distribution strategy. As shown by the study this strategy is tricuspid in nature. Making the product available in the market place at the same time can be accessed in the market space under the wings of comprehensive integrated marketing communication stimuli. Managers should bear in mind that the tactical move is place the product at limited outlets both physically and electronically. The underlying reason is to help control the product image and also dictate prices in the catchment area. Managers wanting to attain a sustainable sales target in the fast moving consumer goods industry should channel their efforts implementing these strategies. Empirically proven that jointly and individually the 'Affran marketing distribution strategies' and sales performance were positively correlated, and the strength of the relationship was moderate. Again, they should synergistically combine both the electronic and social media elements when executing their distribution strategy. They should not ignore integrating marketing communication in the strategy since it is proven empirically to be a driving force towards the attainment of sales performance.

\section{SugGESTIONS FOR FURTHER RESEARCH}

Although the study provides useful insight into distribution strategies and sales performance of selected Fast-Moving Consumer Good (FMCG companies) within the Central Region of Ghana, the results cannot be generalized to the entire region or country as few FMCG companies were selected. The study therefore recommended that, further research should focus on a broader research by including other FMCG companies in the country as a whole.

\section{REFERENCES}

Aaker, D. (2009). Retail Supply Chain Management. New York, London: Auerbach Publications, Taylor \& Francis Group.

Aghion, P., \& Howitt, P. W. (2008). The economics of growth. MIT press.

Ailawadi, K. L., \& Farris, P. W. (2017). Managing multi-and omni-channel distribution: metrics and research directions. Journal of retailing, 93(1), 120-135.

Alrubaiee, L., \& Al-Nazer, N. (2010). Investigate the impact of relationship marketing orientation on customer loyalty: The customer's perspective. International Journal of Marketing Studies, 2(1), 155.

Anuar, A., \& Mohd Yusuff, R. (2011). Manufacturing best practices in Malaysian small and medium enterprises (SMEs). Benchmarking: An International Journal, 18(3), 324-341.

Armstrong, M., \& Taylor, S. (2014). Armstrong's handbook of human resource management practice. New York, USA: Kogan Page Publishers.

Armstrong, G. (2014). Principles of Marketing. Prentice Hall, Englewood Cliffs, NJ.

Arnold R. and Quelch, T. (2008). Balancing marketing and supply chain activities. Journal of Marketing - Theory and Practice, 6, 41- 50.

Baker, M., \& Hart, S. (2008). The marketing books. London, UK: Routledge.
Bikram, S. (2013). An exploratory study of exclusive dealing in channel relationships. Academy of Marketing Science, Journal, 25(3), 201213.

Brunswick, G. J. (2014). A chronology of the definition of marketing. Journal of Business \& Economics Research (Online), 12(2), 105-121.

Cateora, P., c Gilly, M., \& Graham, J. L. (2015). International Marketing. McGraw-Hill Higher Education.

Chigume, W. (2017). An evaluation of distribution strategies in the capital equipment market in Zimbabwe: A case of Co-Plant Technology P/L (2009-2012). Unpublished dissertation, University of Zimbabwe, Harare, Zimbabwe.

Claro, D. P., \& Claro, P. B. O. (2010). Collaborative buyer-supplier relationships and downstream information in marketing channels. Industrial Marketing Management, 39(2), 221-228.

Cohen, J. (1992). A power primer. Psychological bulletin, 112(1), 155-174.

Coughlan, M., Cronin, P., \& Ryan, F. (2007). Step-by-step guide to critiquing research. Part 1: quantitative research. British Journal of Nursing, 16(11), 658-663.

Creswell, J. W. (2014). A concise introduction to mixed methods research. London, UK: Sage Publications.

Creswell, J. W., \& Creswell, J. D. (2017). Research design: Qualitative, quantitative, and mixed methods approaches. New York: Sage Publication.

Davies, R. (2012). Retail and Commercial Planning- RLE Retailing and Distribution. London, UK: Routledge.

Davies, R. L., \& Kirby, D. A. (2012). Retail organisation. Retail Geography (RLE Retailing and Distribution), 7, 156-171.

Diehl, D., \& Spinler, S. (2013). Defining a common ground for supply chain risk management-A case study in the fast-moving consumer goods industry. International Journal of Logistics Research and Applications, 16(4), 311-327.

Doole, I., \& Lowe, R. (2012). International Marketing. London, UK: Sage Publications.

Drucker, P. (2012). The practice of management. London, UK: Routledge.

Edvardsson, B., Tronvoll, B., \& Gruber, T. (2011). Expanding understanding of service exchange and value co-creation: a social construction approach. Journal of the Academy of Marketing Science, 39(2), 327-339.

Etim, N. S., Sunday, E. M., \& Eni, M. G. (2018). The impact of distribution management on Guinness PLC product availability in Calabar. Archives of Business Research, 6(10), 32-46.

Ferrell, O. C., \& Hartline, M. (2012). Marketing strategy, text and cases. New York, USA: Nelson Education.

Frazier, G. L., Maltz, E., Antia, K. D., \& Rindfleisch, A. (2009). Distributor sharing of strategic information with suppliers. Journal of Marketing, 73(4), 31-43.

Fu, F. Q., Richards, K. A., Hughes, D. E., \& Jones, E. (2010). Motivating salespeople to sell new products: The relative influence of attitudes, subjective norms, and self-efficacy. Journal of Marketing, 74(6), 6176.

Garrette, B., \& Karnani, A. (2010). Challenges in marketing socially useful goods to the poor. California Management Review, 52(4), 29-47.

Gateru, J., Muturi, W. M., \& Senaji, T. A. (2015). Influence of product awareness strategy on performance of Fast-Moving Consumer Goods Companies in the bottom of the Pyramid market. Journal of Marketing, 79(2), 121-146.

Gebauer, H. (2009). An attention-based view on service orientation in the business strategy of manufacturing companies. Journal of Managerial Psychology, 24(1), 79-98.

Ghauri, P. N., \& Grønhaug, K. (2005). Research methods in business studies: A practical guide. New York, USA: Pearson Education.

Goi, C. L. (2011). Perception of consumer on marketing mix: Male vs. female. In 2010 International Conference on Business and Economics Research (Vol. 1).

Graham, J., Cateora, P., \& Gilly, M. (2015). International marketing (pp. 122-126). London, UK: Routledge.

Grewal, R., \& Dharwadkar, R. (2012). The role of the institutional environment in marketing channels. Journal of Marketing, 66(3), 8297.

Giunipero, L. C., Hooker, R. E., \& Denslow, D. (2012). Purchasing and supply management sustainability: Drivers and barriers. Journal of Purchasing and Supply Management, 18(4), 258-269.

Haer, R., \& Becher, I. (2012). A methodological note on quantitative field research in conflict zones: get your hands dirty. International Journal of Social Research Methodology, 15(1), 1-13.

Hair, J. F., Black, W. C., Babin, B. J., Anderson, R. E., \& Tatham, R. L. (2010). Multivariate data analysis. New York City, New York: Pearson Education. 
Hauser, J. R., \& Shugan, S. M. (2008). Defensive marketing strategies. Marketing Science, 27(1), 88-110.

Hunt, S. D. (2002). Foundations of marketing theory: Toward a general theory of marketing. ME Sharpe

Karaxha, H., \& Karaxha, H. (2015). The Distribution in International Marketing-Correlation between International and Local Channels in Kosovo. European Journal of Economics and Business Studies, 1(1), 46-53.

Keller, K. L. (2009). Building strong brands in a modern marketing environment. Journal of Marketing Communications, 15(2-3), 139155.

Kotler, P. (2007). Marketing in the public sector. New Delhi, India: Pearson Education.

Kotler, K. B. (2009). Marketing Management. New York, USA: Prentice Hall.

Kotler, P. (2011). Philip Kotler's contributions to marketing theory and practice. In Review of Marketing Research: Special Issue-Marketing Legends (pp. 87-120). Emerald Group Publishing Limited.

Kotler, P., Keller, K. L., \& Lu, T. (2009). Marketing management in China. New York, USA: Prentice Hall.

Krejcie, R. V., \& Morgan, D. W. (1970). Determining sample size for research activities. Educational and Psychological Measurement, 30(3), 607-610.

Kushwaha, T. (2012). Brand extension: a strategy for competitive advantage. Samvad, 5, 18-27.

Leedy, P. D., \& Ormrod, J. E. (2010). What is research. practical research: planning and design. London, UK: Sage Publications.

Lemon, K. N., \& Verhoef, P. C. (2016). Understanding customer experience throughout the customer journey. Journal of Marketing, 80(6), 69-96.

Leroy, K. D. J. (2017). Sales and distribution networks of Fast-Moving Consumer Goods (FMCGS) companies in Ghana. A case study of selected companies in the Kumasi Metropolis. Doctoral dissertation, Kwame Nkrumah University of Science and Technology, Kumasi.

Louckx, Y. (2014). Recommendations for the distribution strategy in changing market environment: Case: Belgian Brewery Van Honsebrouck in Russia. Journal of Marketing Communications, 13(3), 114-125.

Mouzas, S., \& Ford, D. (2009). The constitution of networks. Industrial Marketing Management, 38(5), 495-503.

Musso, F. (2010). Innovation in marketing channels: Relationships, technology, channel structure. Journal of Marketing Communications, 10(2), 13-25.

Mwanza, P., \& Ingari, B. (2015). Strategic Role of Distribution as a Source of Competitive Advantage in Fast-Moving Consumer Goods in Kenya. International Journal of Scientific and Research Publications, 5(4), 54-67.

Ndubisi, N. O., Malhotra, N. K., \& Wah, C. K. (2008). Relationship marketing, customer satisfaction and loyalty: a theoretical and empirical analysis from an Asian perspective. Journal of International Consumer Marketing, 21(1), 5-16.

Neslin, S. A., \& Shankar, V. (2009). Key issues in multichannel customer management: current knowledge and future directions. Journal of interactive marketing, 23(1), 70-81.

Nevin, J. R. (1995). Relationship marketing and distribution channels: Exploring fundamental issues. Journal of the Academy of marketing Science, 23(4), 327-341.

Nyaga, J. (2014). Factors affecting distribution of fast-moving consumer goods in Kenya: A case of Eveready East Africa. International Journal of Social Sciences and Entrepreneurship, 1(12), 290-302.

Njenga, M. N. (2016). Strategies adopted for internationalization of Large Fast-Moving Consumer Goods manufacturers in Kenya. Unpublished doctoral dissertation, University of Nairobi, Kenya.

Olson, E. M., Slater, S. F., \& Hult, G. T. M. (2005). The performance implications of fit among business strategy, marketing organization structure, and strategic behaviour. Journal of marketing, 69(3), 49-65.

Patten, M. L., \& Newhart, M. (2017). Understanding research methods: An overview of the essentials. New York, USA: Taylor \& Francis.

Richter, T. (2012). International marketing mix management: theoretical framework, contingency factors and empirical findings from worldmarkets. Logos Verlag Berlin GmbH.

Rosenbloom, B. (2007). The wholesaler's role in the marketing channel: Disintermediation vs. reintermediation. International Review of Retail, Distribution and Consumer Research, 17(4), 327-339.

Saremi, H., \& Zadeh, S. M. M. (2014). Management of distribution channels. Indian Journal of Science Research, 5(3), 452-456.

Saunders, M. N. (2012). Choosing research participants. Qualitative organizational research: Core methods and current challenges, 3552 .
Saunders, M. N. K., Lewis, P., Thornhill, A., \& Bristow, A. (2015) Understanding research philosophies and approaches: Research methods for business students. London, UK: Sage Publishers.

Segetlija, Z., Mesarić, J., \& Dujak, D. (2011, January). Importance of Distribution Channels-Marketing Channels-for National Economy. In 22nd CROMAR Congress.

Slater, S. F., \& Olson, E. M. (2001). Marketing's contribution to the implementation of business strategy: An empirical analysis. Strategic Management Journal, 22(11), 1055-1067.

Tang, H., Wang, F., \& Wang, Z. (2014). The domestic segment of global supply chains in China under state capitalism. The World Bank.

Verhoef, P. C., Kannan, P. K., \& Inman, J. J. (2015). From multi-channel retailing to omni-channel retailing: introduction to the special issue on multi-channel retailing. Journal of Retailing, 91(2), 174-181.

Vibhash, G., \& Lakshmi, N. (2008). Sales and Distribution Management in Newspaper Industry. Retrieved, October, 12, 2015.

Walker, G., \& Day, R. (2012). Fuel poverty as injustice: Integrating distribution, recognition and procedure in the struggle for affordable warmth. Energy Policy, 49, 69-75.

Witcher, B. J., \& Chau, V. S. (2010). Strategic management: Principles and practice. Cengage Learning EMEA.

Wright, A. (2012). Technology as an enabler of the global branding of retail financial services. Journal of International Marketing, 10(2), 83-98.

Yeboah, A., Owusu, A., Boakye, S., \& Owusu-Mensah, S. (2013). Effective distribution management, a pre-requisite for retail operations: a case of Poku trading. European Journal of Business and Innovation Research, 1(3), 28-44.

Yin, R. K. (2017). Case study research and applications: Design and methods. London, UK: Sage publications.

Zhao, X., Niu, R. H., \& Castillo, I. (2010). Selecting distribution channel strategies for non-profit organizations. European journal of Marketing, 44(7/8), 972-996.

Zikmund, R., \& d'Amico, T. P. (2011). Marketing action in networks. European Journal of Marketing, 4(11/12), 1271-1291. 